\title{
Improving Factors of Divorce Rate in Sabang City
}

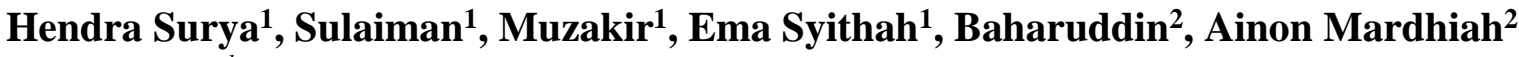 \\ ${ }^{1}$ Lecturer in Sekolah Tinggi Ilmu Syariah (STIES) Al-Aziziyah Sabang, Indonesia \\ ${ }^{2}$ Student in Sekolah Tinggi Ilmu Syariah (STIES) Al-Aziziyah Saban, Indonesia \\ tgkdrsaiful@gmail.com
}

\begin{abstract}
The purpose of this study was to look at the factor of increasing divorce rates in the city of Sabang. This research integrates library research and field research using a qualitative approach. This study uses. descriptive method of analysis The highest results of the study showed that the factor of increasing divorce in Sabang City was caused by; first, continuous disputes and disputes amounted to 80 cases, secondly, leaving one party numbered 38 cases, third, economic (family needs not met) as many as 9 cases, fourth, domestic violence in 5 cases, and fifth, sentenced to imprisonment (involved in the use of narcotics) totaling 4 cases, the data is the data of the last three years. Whereas prevention efforts to avoid divorce are carried out by conducting marriage counseling conducted by the Office of Religious Affairs in the Sabang City area, at least one week before the implementation of the marriage contract, this guidance activity is mandatory for couples to marry, besides the Shari'ah Court of Sabang also conducted mediation with every party who filed a divorce or divorce divorce, out of the 63 cases of mediation cases that entered, only 5 cases of mediation were successfully mediated in the last three years and if the mediation attempt was unsuccessful a register was held to proceed to the trial stage.
\end{abstract}

Keywords : divorce; Thalaq; claims; mediation

\section{Introduction}

Getting married is one phase of life that is commonly done by every adult human, ready physically and mentally, and has a sense of responsibility in building a household. Every person who has fulfilled these requirements is recommended to set his feet to the level of marriage. It is this level that marks a phase of life that is very important for one's survival in the future. Compared to living alone, family life has many challenges and also contains a number of positive expectations. No doubt in marriage there are many benefits if you can manage it well.

In connection with that, the Marriage Law No. 1 of 1974 Article 1 defines marriage as an inner bond between a man and a woman as a husband and wife with the aim of forming a happy and eternal family based on the One Godhead. ${ }^{1}$ In other words marriage can also be interpreted as a form of agreement between husband and wife wife who must work together and be responsible against all household affairs. In the KHI the purpose of marriage is to realize the sakinah, mawaddah and rahmah domestic life. ${ }^{2}$

In addition, the purpose of the marriage as God said in the letter Ar-Rum verse 21 below: Meaning: And of His signs is that He created for you from yourselves mates that you may find tranquillity in them; and He placed between you affection and mercy. Indeed in that are signs for a people who give thought. [ QS. Ar Rum 30:21]

\footnotetext{
${ }^{1}$ Amiur Nuruddin, Azhari Akmal Taringan, Hukum Perdata Islam di Indonesia, Jakarta : PRENADA MEDIA, 2004, p. 42-43.

${ }^{2}$ DEPAG RI. Kompilasi Hukum Islam di Indonesia, Bab II, Pasal 3. Jakarta :Direktorat Jenderal Pembinaan Kelembagaan Agama Islam. 1997, p, 14
} 
Marriage constitutes the sunnah of the Prophet Muhammad, sunnah in the sense of exemplifying the actions already committed by the Prophet Muhammad. Marriage is required that man have a rightful offspring and family towards a happy life in the world and the afterlife, with the ridha of God SWT, ${ }^{3}$ and this has been hinted at from before, 3 and is already widely described in the Quran.

Meaning : Marry those of you that are single, (whether men or women), ${ }^{50}$ and those of your male and female slaves that are righteous. ${ }^{51,52}$ If they are poor, Allah will enrich them out of His Bounty. ${ }^{53}$ Allah is Immensely Resourceful, All-Knowing. [QS. An-Nuur Ayat 32]

The essence of marriage is the realization of inner well-being or immaterial material well-being for all family members consisting of husband and wife of the child and all of the extended family husband and wife. Unification of men and women in marital institutions is expected to create a strong, peaceful, loving and prosperous family building (Esposito 1982,16). A strong family building is a condition for the realization of a quality and prosperous society. If a family building is cracked and then collapsed and divorced, it will be difficult to realize a peaceful and quality society. This is where the importance of manifesting

strong family to create a prosperous society. ${ }^{4}$

The ideal condition for the realization of a family building like that is the hope of all those involved in marriage when they are in the process of the qabul agreement. Along with the passage of time and the dynamics of the development of the household, there were many obstacles and disturbances in realizing or strengthening the nature of marriage. Husbands and wives make decisions to end the marriage by bearing the consequences of the divorce. Household buildings have collapsed and divorce is the husband's last choice. ${ }^{5}$

Divorce in Islamic law or fiqh is known as thalaq and khuluk. Thalak is a divorce whose initiative comes from a husband, while khuluk is a divorce with an initiative originating from a wife. Thalaq and khuluk are understood as legal actions which result in the release of the marital husband and wife's marriage in a manner that is profane or in accordance with good customs. This divorce is a legal action that is lawful or permissible but is the most despised act by Allah SWT. ${ }^{6}$

The last years, especially in the Sabang area of Aceh Province, the rate of divorce is relatively high, compared to the population of only around 33,782 people. $^{7}$ Increasing

\footnotetext{
${ }^{3}$ Wahyu Wibisana, (2016), Pernikahan Dalam Islam, Jurnal Pendidikan Agama Islam (Ta'lim) Vol. 14. No.2, p 185

${ }^{4}$ Ali Imron, (2016), Memahami Konsep Perceraian dalam Hukum Keluarga, Jurnal Buana Gender, Vol. I,

No. I, Januari - Juni, p. 16

${ }^{5}$ Ali Imron, (2016), Memahami Konsep ...

${ }^{6}$ Ali Imron, (2016), Memahami Konsep ...

${ }^{7}$ Bappeda Kota Sabang, Sabang Dalam Angka (Sabang In Figures 2014), Sabang: BAPPEDA Kota Sabang, 2014, hlm. 35।
} 
divorce rates in Sabang, almost one hundred percent of cases that enter the Sharia Court Sabang ended with divorce decisions by 2015. Of the 57 cases that entered 54 of them ended in divorce decisions. Cases handled by the Sharia court in the Sabang can be specified, namely divorce cases of 20 cases, divorce 37 cases, while the remaining cases from 2014 are as many as 22 cases. For cases that were decided each divorce was 19 cases, divorced 35 cases and others as many as 25 cases. $^{8}$ In addition, Sabang which only consisted of two Districts namely Sukajaya and Sukakarya District, with 57 cases that entered the Sharia Court The city of Sabang is classified high.

The high divorce rate in Sabang is caused by a variety of factors and problems in the family, thus making harmony between husband and wife disturbed and ultimately leading to divorce. The consequences of divorce are also felt by children, rather than their parents who are divorced, so they cannot feel together or live together with their two masters in one house. The psychological condition of children is also disturbed by the divorce that occurs to their parents, especially to children aged 17 years and under.

Such a condition is certainly very dangerous for children who are in unhealthy families, sometimes it is not uncommon to find children who were originally well-behaved to behave badly, such as the example of the number of teenage children who are trapped in drug cases. This happened initially by family factors that were less harmonious, so they took shortcuts and got caught using Narcotics with the aim of eliminating stress or the problems they experienced around their families.

In addition, the issue of divorce is not just the breakup of husband and wife relations. However, there are other things that have a very negative impact behind the occurrence of divorce, namely the disruption of the soul or psychology of children from the fruit of the marriage that has been carried out, so that it can have a fatal impact on the change in children's behavior towards the negative.

Based on the above facts, it is very interesting to do research, the factors that cause the increase in divorce rates in Sabang. It is expected that with this research, it will become a reference for relevant parties to get a solution in reducing the level of divorce in the city of Sabang in the future.

Based on the background of the above problems, the authors are interested in conducting research on the level of divorce in Sabang, with the title: "Factors Increasing Divorce Rates in Sabang"

\section{Review of Literature}

\subsection{Thalaq Law}

Talking about marriage matters means talking about the problem, because talaq is part of the marriage discussion and is common in marriage. Talaq is to eliminate marriage ties with certain lafaz or lafaz-lafaz which means a certain pronunciation. ${ }^{9}$ Talaq only belongs to the husband, not to the wife. Talaq is also suggested in religion Islam is based

\footnotetext{
${ }^{8}$ http://.rri.co.id/bandaaceh/post/erita/248586?ragam_cerai_kian_tinggi_mahkama_syariah_sabang_mitra_masya rakat_hargai_tali_pernikahaa.html

${ }^{9}$ Mughni al-Muhtāj, Vol. 3, Vol. 44, (al-Maktabah al-Syamilah), p. 279
} 
on the Qur'an, sunnah and ijma. ${ }^{10}$ As for the Qur'an verses explain the problem of tuning is:

"Talaq (which can be reviewed) twice. after that can refer again by the way who speak or divorce in a good way." 11

"O Prophet, if you divorce your wives, then you should divorce them when they can (face) their iddah (which is natural)."

Whereas from the sunnah is the saying of the Prophet:

"Nothing God has forbidden, but God hates him very much." 12

"Surely the Messenger of Allah. have mentalaq Khafsah then the Messenger of Allah reconciles. "13

"Ibn Umar's hadith, that he was Thalaq his wife when her menstrual period, the Prophet. order it to reconcile then it is only possible to re-order it after the sacred if you want. "

Jumhur fukaha argues that the law of origin is altered. But according to others from the Faculty of Law argued that the law was originally there is haram. Even so, it is certain that Jurisxprudence agreed all that the law applies to taklifi as well. So sometimes the law is mubah, circumcision, obligatory, makruh and haram. ${ }^{14}$ All the laws of the thalaq there are separate classifications to determine them.

1. Thalaq is obligatory if the husband is reluctant to associate his wife according to the juridical terms of the law.

2. Thalaq circumcision if the wife has neglected to fulfill the rights of Allah which is obligatory upon her, such as prayer and other lines. Such is also true if the wife asks for the difficulty.

3. Thalaq is changed when he wishes to refuse his wife's bad morals and bad associations or husbands do not love wives.

4. Thalaq makruh if there is no wife the characteristics that are attractive to the husband.

5. Thalaq haram is talaq which is performed during the wife's menstrual period or during the holy period but has been received. This talaq is called talaq bid'ah because it never happened at the time of the Prophet.

\section{Position of Wife After Divorce}

Marriage is carried out in accordance with Islamic law and positive law, if the marriage relationship is broken between husband and wife in all its forms, then the applicable law thereafter is:

a. The relationship between the two is foreign in the sense that they must separate and may not look at each other, let alone associate as a husband and wife, as applies

\footnotetext{
${ }^{10}$ QS. Al-Baqarah: 229

${ }^{11}$ QS. al-Nur: 1.

${ }^{12}$ Sunan Abu Daud, Vol. 2, (al-Maktabah al-Syamilah), p. 361.

${ }^{13}$ Sunan Abu Daud, Vol. 2, (al-Maktabah ..., p. 712.

${ }^{14}$ Ibn Hajr, Mughni al-Muhtaj, Vol. 3, (al-Maktabah al-Syamilah), p. 279.
} 
between two people who are foreign. Marriage is a contract that allows a man to associate with a woman as a husband and wife. The breakup of marriage restores the halal status he gets in marriage, so he returns to his original status, which is haram.

b. The requirement to give mut'ah is the giving of a husband to a divorced wife as compensation. This is different from mut'ah as a dowry if the wife is divorced before being interred and before the number of dowry is not determined, it is not mandatory for the husband to give dowry, but it is balanced with a gift called mut'ah.

In the obligation to give mut'ah there are differences of opinion among ulama. The Zahiriyah group believes that mut'ah is obligatory. The mandatory legal basis is the word of God in Surat al-Baqarah verse 241 below:

Meaning : And for divorced women is a provision according to what is acceptable - a duty upon the righteous. (QS. Al-Baqarah ayat 241)

Malikiyah Ulama argues that mut'ah is a sunnah law, because the word اقدى لـ أنيقتم at the end of the verse indicates that the law is not mandatory. Certain other groups. However Hanafiyah argues that the law must apply to husbands who question their wives before being interred and before the number of dowries is not determined, as explained by Allah in Al-Baqarah verse 236 as follows:

Meaning : There is no blame upon you if you divorce women you have not touched nor specified for them an obligation. But give them [a gift of] compensation - the wealthy according to his capability and the poor according to his capability - a provision according to what is acceptable, a duty upon the doers of good. (QS. AlBaqarah ayat 236)

Jumhur argued that Mut'ah was only for divorce whose initiative came from a husband, such as thalaq, except if the number of dowry had been determined and divorced before socializing.

In addition, the husband must provide for his wife during the period of prayer. Iddah is Arabic which comes from the root word adda-ya'uddu-atanidatan and the plural is "idad which means word (etymology) means:" count "or" count ". This word is used for the purpose of iddah because in that period the woman who was waiting waited for the passage of time.

In the fiqh the definition of $i d d a h$ is short and simple in between: a waiting period passed by a woman. Because of the simplicity of this definition he still needs an explanation, especially about the awaits he is waiting for, why wait, and what is waiting.

To answer what is waiting and why he must wait, al-Shan'aniy put forward a more complete definition as follows:

"The name for a time when a woman at that time has the opportunity to remarry because of her husband's death or divorce with her husband "15

${ }^{15}$ Deasy Caroline, Pelaksanaan Eksekusi Nafkah Anak diPengadilan Agama, (Artikel Jurnal Mimbar Hukum), Jakarta, Al-Hikmah dan DITBINBAPERA Islam No. 42 Tahun X 1999, p. 322-324. 
From the various definitions stated above, the essence of the iddah can be drawn up as follows: "a period that must be awaited by a woman who has been renting from her husband to be able to remarry to know her womb or to carry out Allah's orders.

The wife who has divorced from her husband still gets the rights of her ex during the iddah period, because in that period she may not have married with other men, but that right is not perfect as it applies during the marriage relationship. The form of rights received does not depend on the length of time that is lived, but depends on the form of divorce experienced.

A divorced wife from her husband in relation to the rights she receives is grouped into three types, namely:

1) A wife divorced in the form of thalaq raj'iy, the right she receives is full as applicable before being divorced, both in the form of shopping for food, for clothing and also a place to live. This is an agreement of scholars.

2) A wife divorced in the form of thalaq bain sughra or bain kubra and she is pregnant. In this case the ulama agreed that he was entitled to nafaqah and place of residence.

3) The right of the wife left by her husband to die. In the case of a wife in a state of pregnancy the ulama agrees to say that she has the right to livelihood and place of residence, but if the wife is not in a state of pregnancy the ulama is of differing opinion. Some scholars, among them Imam Malik al-Syafi'iy and Abu Hanifah, argued that the wife in the dead iddah was entitled to a place to live.

\subsection{Rights and Obligations of Husband and Wife After Divorce}

After the divorce, the husband and wife have the right and obligation to both care for the child. Child care in Arabic is referred to as "Hadhanah". The fiqh scholars define hadhanah as doing the voting of young children, both men and women, or those who are already big but not yet mumayyiz, providing something that makes their good, keeping it from something that hurts and destroys it, educates the body, spirit and mind, to be able to stand up face life and assume responsibility. ${ }^{16}$

A child at the beginning of his life to a certain age requires someone else to help him in his life, such as eating, clothes, cleaning themselves, even to get up and sleep. Therefore, people who look after them need to have compassion, patience, and have the desire that the child is good (godly) later on. In addition, there must also be sufficient time to carry out the task, and those who have these conditions are women.

A father is obliged to pay wages for deduction and hadhanah, also must pay the cost of renting a house or equipment if the mother does not have her own home as a place to care for her small child. He is also obliged to pay the salary of a housekeeper or provide the helper if the mother need it. ${ }^{17}$

Among the obligations of parents to their children is to provide a living. A father is obliged to provide a living guarantee for his child, both clothes, shelter and other needs, even though the marriage relationship of the child's parents is broken. A divorce does not result in the loss of the obligation of parents to continue to provide their children to adulthood or to be able to stand alone.

\footnotetext{
${ }^{16}$ Abd. Rahman Ghazaly, Fiqh Munakahat, Cet 2. Jakarta : Kencana, 2006, p. 175.

${ }^{17}$ Abd. Rahman Ghazaly, Fiqh ..., p. 187-188
} 
Divorce events are catastrophic for children, children will no longer be able to enjoy parental affection simultaneously which is very important for their mental growth, not infrequently the breakup of households results in neglect of childcare. That is why in the teachings of Islam divorce must be avoided as much as possible even as the most hated acts of Allah SWT. For children born, divorce from their parents is something that will shake their lives and will have a negative impact on their growth and development, so that children can be the ones who suffer the most from divorce old. ${ }^{18}$

In Islamic teachings, there are two periods of child development in relation to parental custody, namely the period before mumayyiz (children cannot distinguish between what is beneficial and what is harmful to them, from birth to seven or eight years, according to Compilation of Islamic Law to old age 12 years, and after mumayyiz. ${ }^{19}$ Before mumayyiz children, mothers are more entitled to exercise child custody because mothers better understand the needs of children with affection, especially children at that age desperately need to live near their mothers.

The period of mumayyiz starts when the child is simply able to distinguish which ones are dangerous and beneficial for him, this starts from the age of seven to the time of adulthood (baliginous). During this time the child can choose and decide whether to choose to join his mother or father. But under certain conditions when the child's choice is not beneficial for the child, for the sake of the child the judge may change the decision and determine what is wrong for the child. ${ }^{20}$

With the divorce occurring, the court can require ex-husbands to provide livelihood costs or determine obligations for ex-wives. As mothers or fathers they are still obliged to care for and educate children and if there is a dispute regarding the mastery of the child the court gives a decision solely based on the interests of the child. A father is responsible for all the maintenance and education costs that are needed by the child and if the father is unable to fulfill his obligations the court can determine if the mother is carrying it.

All hadlanah costs and the living of the child are borne by the father according to his ability, at least until the child is mature and can take care of himself or until the age of 21 years. If there is a dispute regarding the hadlanah and the livelihood of the child, it is the court that decides it. The obligation of parents to maintain and educate children remains inherent even though the marriage relationship of parents breaks up.

If the hadhanah holders cannot guarantee the physical and spiritual safety of the child, the court can transfer the hadlanah rights. All hadlanah costs and the living of the child are borne by the father according to his ability until the child is an adult and can take care of himself (21 years).

Parents are the first to be responsible for the welfare of the child, the obligation to maintain and educate the child in such a way that the child can grow and develop into someone who is intelligent, healthy, devoted to parents, noble character, fearing the Almighty God and willing and capable of continuing the ideals of the nation.

\footnotetext{
${ }^{18}$ Satria Effendi M. Zein, Problematika Hukum Keluarga Islam Kontemporer, cet-2, Jakarta : Kencana, 2004, p. 166.

${ }^{19}$ Pasal 106 KHI

${ }^{20}$ Satria Effendi M. Zein, Problematika Hukum Keluarga Islam Kontemporer..,p. 181.
} 
While a child is not yet 18 years old or unmarried he is under the authority of his parents who will represent him regarding legal actions inside and outside the court. Even though holding the power of attorney, parents may not transfer their rights or mortgage their property unless the child's interest is desired. If the parent neglects his obligations or behaves very badly, his authority over the child can be revoked for a certain period of time, revocation of parental authority can be requested by a parent, the child's family in a straight line up, adult siblings or by an official authorities, the revoked parental authority does not eliminate its obligation to remain provide maintenance costs to children. ${ }^{21}$

Both parents must maintain and educate their children as well as possible until their children marry or can stand alone. The obligation of parents to maintain and educate children remains inherent even though the marriage relationship of parents breaks up. Children have certain rights that must be fulfilled by parents, whereas parents also have rights that must be fulfilled by their children. The right of the child to get a decent livelihood, including clothing, food, education and health is a child's livelihood (alimentation) which must be fulfilled by parents, especially fathers, both during marriage and after divorce occurred. ${ }^{22}$

\section{Research Method}

Research integrates library research (library research) and field research using a qualitative approach. This study uses a descriptive analysis method, trying to describe what is seen, heard and a picture that is in the field about the factors that incre ase divorce rates in Sabang. According to Muhammad Nazir, the descriptive method is a method of examining status human group, an object, a condition, a system of thought or a class of events in the present. The purpose of this study is to draw a picture or painting systematically, the properties and relationships between the phenomena investigated. ${ }^{23}$

The objects of research chosen in this study were the Sabang Sharia Court, the Office of Agama Affairs in Sukajaya and Sukakarya District Office of Religious Affairs, as well as parties related to divorce and claim divorce taken as a sample of 45 respondents.

\section{Discussion}

Sabang is an archipelago located at the far end of the island of Sumatra, Sabang itself is also included as one of the tourism areas, which consists of two sub-districts namely Sukajaya and Sukakarya Districts. The population of Sabang continues to increase from year to year, in 2017 the population of Sabang was 33,978 people, experiencing growth of 1.06 percent compared to the previous year. Population growth in Sukajaya District is 1.02 percent, lower than Sukakarya Subdistrict which is 1.10 Percent. $^{24}$

While the number of marriages in Sabang per 2017 with details of Sukajaya District with total 115 marriages and Sukakarya Districts with total 101 marriages. Whereas in

\footnotetext{
${ }^{21}$ Deasy Caroline, Pelaksanaan Eksekusi Nafkah ..., p. 39

${ }^{22}$ Deasy Caroline, Pelaksanaan Eksekusi Nafkah ..., p. 40

${ }^{23}$ Sugiano, Metode Penelitian Kualitatif..., p. 99

${ }^{24}$ BPS kota sabang, kota sabang salam angka tahun 2018, badan statistika Kota Sabang, Sabang, 2018 p. 33
} 
2018 to November in Sukajaya district the implementation of marriages was recorded around 105 marriages and Sukakarya Districts numbered 130 marriages.

Data on the number of marriages of each Subdistrict above are data obtained from the Sukajaya and Sukakarya District Affairs Office Sabang. Based on the data above shows that the level of marriage in Sukajaya District from 2016 to 2018 has decreased the number of marriages. It is different from Sukakarya District from the year 2016 to 2018 there was an increase in the number of marriages, even though in 207 there was a decline.

Along with the increase and decrease in the number of marriages in Sabang, on the other hand the increase in divorce rates that occur in Sabang is also high, this problem can be seen from the number of divorces that occurred in 2016, 2017 and 2018, the following:

Table 1. Number of applicatiion for divorce and divorce in the city of Sabang 2016, 2017 and 2018

\begin{tabular}{cccc} 
No. & Year & Thalaq of Divorce Application & Divorces \\
& 2016 & 18 & 45 \\
\hline 1. & 2017 & 11 & 37 \\
\hline 2. & 2018 & 13 & 37 \\
\hline 3. & Total & 42 & 119 \\
\hline \multicolumn{3}{c}{161 Cases } \\
\hline
\end{tabular}

Source : Mahkamah Syari'ah Kota Sabang

The number of cases that occurred in Sabang on average each year more than 40 cases of divorce applications submitted to the Syari'ah Court of Sabang, which were divided into two types of cases, namely divorce cases and divorce. Among the two workers, the most entered divorce application is from a divorce case, or it can be concluded that from the women's side the most filed for a divorce request to the Syari'ah Court of Sabang.

There are various kinds of factors that cause high divorce rates in Sabang, thus creating disharmony in the household. Based on data from the Syari'ah Court, there are several factors that lead to divorce, including leaving one of the parties, sentenced to prison, domestic violence, continuous disputes and arguments, and economic factors. The following are details of the causes of high divorce rates in Sabang.

Table 2. Recapitulation of the cause of divorce in the city of Sabang 2016, 2017 and 2018

\begin{tabular}{|c|c|c|c|c|c|c|c|}
\hline No. & $\stackrel{\text { 련 }}{2}$ &  & 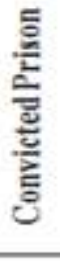 & 㕆 & 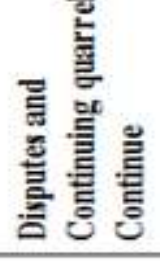 & 豆 & 퐁 \\
\hline 1. & 2016 & 24 & 1 & 2 & 29 & 4 & 60 \\
\hline 2. & 2017 & 8 & 2 & 1 & 32 & 5 & 48 \\
\hline 3. & 2018 & 6 & 1 & 2 & 19 & 0 & 28 \\
\hline \multicolumn{2}{|c|}{ Total } & 38 & 4 & 5 & so & 9 & 136 \\
\hline
\end{tabular}

Source : Mahkamah Syari'ah Kota Sabang 
The data in the table above shows that the highest factor that results in disharmony in the household leads to divorce, namely :

1. Continuous disputes and arguments in the household.

This factor was triggered because one of the parties no one succumbed when there was a quarrel between husband and wife, sometimes there were things that small problems could trigger fights and there were also fights caused by lack of livelihood, so the wife felt uncomfortable with the economic conditions in the family inadequate, the condition of impatience that leads to divorce and this factor is the biggest cause of divorce.

\section{Leaving one party}

One of the parties left the house without notice to the husband or wife and never returned for years, some even did not return at all

\section{Economy}

The factor of the husband's inability to make ends meet is for his family, so that the wife filed a divorce lawsuit to Mahakamah Syari'ah, Sabang. Most of what happened in this case was because of the lack of financial well-being, this was motivated because the low level of education caused the difficulty in getting permanent employment, forced to work only odd jobs so that they could not meet the family's needs.

\section{Domestic Violence (Domestic Violence)}

Domestic violence still often occurs in the family environment, even the same case and the same party had previously been reconciled at the local Village Head's office, which was attended by local religious leaders and traditional leaders of the Gampong (Village), but it continued to return to divorce was filed with the Syari'ah Court of Sabang, because his wife was unable to be patient because he had received harsh treatment from her husband, even though he had tried to avoid divorce.

\section{Convicted Prison.}

The cause of divorce in Sabang there is also the result, as the husband was involved in drug crimes that culminated in prison convicts, so it is by this factor that the wife was embarrassed by the husband's conduct and ultimately filed for a convenience divorce to the Sharia Court of Sabang.

Whereas the efforts that related agencies can make in order to prevent divorce in Sabang are by way of marriage guidance, before marriage determination. The implementation of marriage guidance was implemented 1 week before the implementation of marriage certificates, as for the material taught between them; the issue of childbirth (acade), the requirement of marriage, the responsibility of the wife's husband in the running of the household, the cause of divorce, the remorse of divorce and mediation before being devolved to the Sabang Syari'ah Court. And the Syari'ah Court of Sabang, also co-opting the mediation of divorce cases, things were done in order to prevent rising divorce rates in Sabang. 


\section{Conclusion}

The divorce is a thing that is lawful to do but hateful to God. There are many factors that lead to high divorce rates as occurring in Sabang, with an overall total population of 33,878 and consisting of two District, certainly with divorce figures occurring annually of 40 more cases, suggesting Sabang is particularly vulnerable to divorce. Factors of Improving Divorce Numbers in Sabang.

a. Continuous disputes and arguments in the household.

b. Leave one party

c. Economy / not fulfilled livelihood needs

d. Domestic Violence (Domestic Violence)

e. Sentenced to Prison, the husband was involved in committing a crime of using narcotics.

\section{References}

Abd. Rahman Ghazaly, Fiqh Munakahat, Cet 2. Jakarta : Kencana, 2006.

Ali Imron, Memahami Konsep Perceraian dalam Hukum Keluarga, Jurnal Buana Gender, Vol. I, No. I, Januari - Juni 2016.

Amiur Nuruddin, Azhari Akmal Taringan, Hukum Perdata Islam di Indonesia, Jakarta: PRENADA MEDIA, 2004.

Bappeda Kota Sabang, Sabang Dalam Angka (Sabang In Figures 2014), Sabang: BAPPEDA Kota Sabang, 2014.

BPS Kota Sabang, Kota Sabang Dalam Angka Tahun 2018, Badan Pusat Statistik Kota Sabang, Sabang, 2018.

Deasy Caroline, Pelaksanaan Eksekusi Nafkah Anak diPengadilan Agama, (Artikel Jurnal Mimbar Hukum), Jakarta, Al-Hikmah dan DITBINBAPERA Islam No. 42 Tahun X 1999.

DEPAG RI. Kompilasi Hukum Islam di Indonesia, Bab II, Pasal 3. Jakarta

Direktorat Jenderal Pembinaan Kelembagaan Agama Islam. 1997

http://www.rri.co.id/bandaaceh/post/berita/248586/ragam/angka_cerai_kian_tinggi_ma hkamah_syariah_sabang_minta_masyarakat_hargai_tali_pernikahan.html

J. Suparno, Metode Research, Cet. V, Jakarta:Rineka Cipta, 2012.

Lexi J. Moleong, Penelitian Kualitatif, Bandung: Remaja Rosdakarya, cet.Ke-13, 2010.

Mattew B. Miles dan A. Michael Huberman, Analisis Data Kualitatif, Terj. Tjetjep Rohindi, Jakarta: UI Pers, cet 12, 2013.

Muhammad Nazir, Metode Penelitian, Cet. IV Jakarta: Rajawali, 2013.

Satria Effendi M. Zein, Problematika Hukum Keluarga Islam Kontemporer, cet-2, Jakarta : Kencana, 2004.

Sugiono, Metode Penelitian Pendidikan,Pendekatan Kuantitatif dan $R \& D$, Bandung: Al-Fabet, Edisi III, 2010.

Wahyu Wibisana, Pernikahan Dalam Islam, Jurnal Pendidikan Agama Islam(Ta'lim) Vol. 14. No.2 Tahun 2016. 